\title{
HERITAGE SITES: THE PROBLEM OF ECONOMIC, SOCIAL AND CULTURAL VALUATION
}

\author{
RONI DEMIRBAG ${ }^{1}$, VIVIENNE SAVERIMUTTU ${ }^{1}$, YIYANG LIU ${ }^{1} \&$ SAJAN CYRIL ${ }^{2}$ \\ ${ }^{1}$ School of Business, Western Sydney University, Australia \\ ${ }^{2}$ Australian Institute of Higher Education, Australia
}

\begin{abstract}
The flooding of Hasankeyf raises an important problem of economic valuation of heritage sites. Hasankeyf, located on the Tigris river in South-eastern Turkey, prior to its flooding by the Ilisu dam project, was considered to be one of the oldest continuously inhabited human settlements that goes back 12,000 years. The Turkish government justified the construction of the dam by emphasising its economic benefits despite strong objections from other stakeholders who were concerned about the impending loss of cultural and social heritage. The paper highlights the historical and cultural significance of Hasankeyf, and the impact of the dam from the perspective of the Government and other stakeholders. The economic benefits of potential infrastructure developments often outweigh the benefits of the cultural and social value of heritage. Valuing heritage sites is inherently subjective and difficult to quantify. The focus of this paper is to determine a rigorous method of quantifying the economic value of cultural and social heritage. Treating cultural heritage sites as public goods the application of three methods of valuation is assessed with reference to Hasankeyf: The Coase theorem, the travel cost method and the contingent valuation method. These methods are examined in terms of practical application, socio-economic level of population and political will. Unlike the Coase theorem, the travel cost and the contingent valuation methods could have applied in Hasankeyf to assess the economic value of its cultural loss with support from the international community. However, the low socio-economic level of the local population and lack of political will would have proved counterproductive. Nevertheless, where the political will exists, these methods are practical and proven to be rigorous in their application. Thereby transforming cultural and social heritage into economic value that could endure in the future.
\end{abstract}

Keywords: Hasankeyf, loss of heritage sites, Ilisu dam, valuation of social and cultural heritage.

\section{INTRODUCTION}

In 1972, at the UNESCO World Heritage "Convention Concerning the Protection of the World Cultural and Natural Heritage", works of cultural heritage were categorised as monuments, groups of buildings and sites that are works of man or combined works of man and nature 'that are outstanding and of universal value' from various points of view. Natural heritage was considered as natural features consisting of physical and biological formations, geological and physiographical formations and precisely delineated areas which constitute the habitat of threatened species, natural sites or precisely delineated natural areas of outstanding universal value from the point of view of science, conservation or natural beauty [1]. The destruction of natural and cultural heritage sites can occur due to decay and natural disasters but also due to the actions of Governments facing development pressures as a result of population growth or armed conflicts.

In the face of such destruction, Organisations such as UNESCO, the International Union for Conservation of Nature (IUCN) and many other non-governmental organisations (NGOs) 'seek to preserve a balance in this interaction between man and nature' by actively sponsoring the preservation of these natural and cultural heritage sites for future generations by explicitly recognising their importance as 'legacies from the past' and 'irreplaceable sources of life inspiration' [1]. In promoting a universal attitude of 'stewardship' [2] these organisations are implicitly fostering the building of 'social capital', widely recognised as the underlying 
source of differences in levels of socio-economic development leading to a higher quality of life [3] and democratic governance that strive to achieve justice and stability [4].

Hasankeyf (Fig. 1), was a unique historical site of cultural and natural heritage in the Republic of Turkey. The construction of the Ilisu dam, due to its capacity for energy production, was promoted by the Government and led to the inundation of Hasankeyf and surrounding archaeological sites. While the local population and international communities bemoaned the resulting loss of the cultural and social heritage, its economic benefits were advocated by the Government. The Government reasoned that the building of the dam would result in significant benefits to the country including the elevation of the socio-economic status of the population of Hasankeyf.

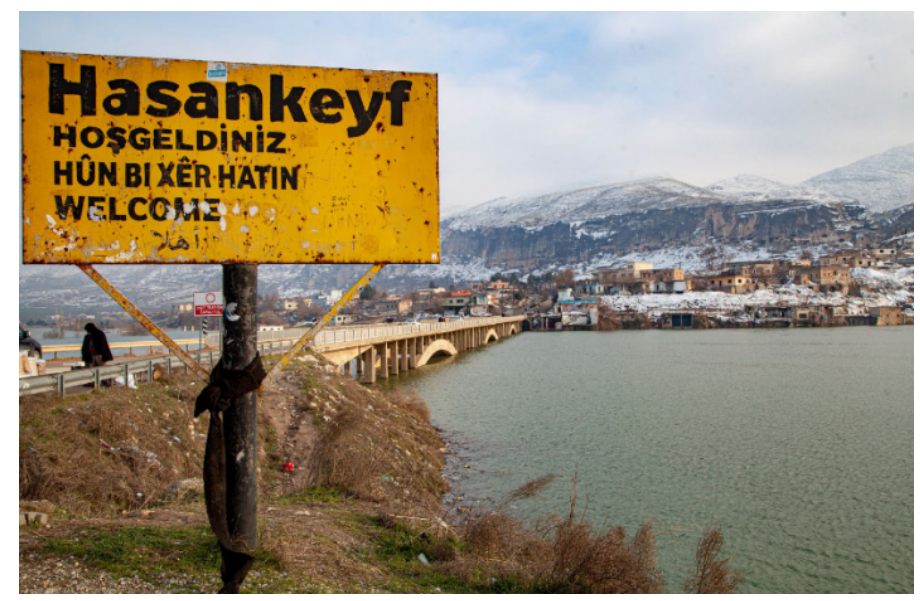

Figure 1: Hasankeyf, south east Turkey.

The focus of this paper is to assess methods that are able to quantify the future benefits that can ensue from cultural and social heritage such that their economic value can be taken into account when threatened by large development projects. The Methodology involves a review of the applicability of three different methods of evaluation of cultural and social heritage sites with respect to Hasankeyf. The assumptions and conditions under which each method is applicable, and whether or not they may be effectively and practically employed for heritage sites such as Hasankeyf will be critically examined. Identifying what could have worked for Hasankeyf will enable us to apply it more effectively in assessing the economic value of cultural heritage which are likely to be lost due to developmental projects in the future.

Section 2 highlights the uniqueness and importance of Hasankeyf as a historical site of cultural and natural heritage. Section 3 details in brief the origins of the Ilisu dam project, its impact during the life of the project, the Government's position on the economic and environmental benefits of the project, and the perspectives of other stakeholders who wish to prevent the loss of heritage due to the project. Section 4, is a pictorial abstract of the flooding of Hasankeyf with highlights of its impact on its people and culture. Section 5 while examining counter measures in an attempt to save Hasankeyf, explores the feasibility of different methods of valuing loss of cultural heritage and the conditions under which they are applicable. The paper concludes by highlighting important insights for future application in cases where development projects threaten significant cultural and social heritage sites. 


\section{HASANKEYF}

Hasankeyf is located in the Southeast region of Turkey near the Batman Province. It is one of the oldest continually occupied settlements in the world with an estimated history dating back approximately 12,000 years [5]. A medieval settlement, located on approximately 660 ha, Hasankeyf lies along the Tigris River, which extends all the way down to the Arab Gulf [6]. The ruins of the 4-arch bridge (old Hasankeyf bridge) built by the Artuqids stood (until recently) on the River Tigris. Man-made cave dwellings, archaeological masterpieces from Hasankeyf, date back to the Neolithic period [5].

There are three main reasons why Hasankeyf is a globally important heritage site. Having such a long history provides an invaluable research opportunity for archaeological excavation and study in order to further our collective understanding of the early stages of human civilisation. Various studies have been conducted that shed important light on the early transition from the Neolithic period [7]-[10].

Secondly, being located on major trade routes had bestowed Hasankeyf with geostrategic importance for various Empires and States during its very long history. Being part of the Silk road, artefacts from various stages belonging to different cultures and civilisations made Hasankeyf a very important heritage site that could not be assigned solely to one single ethnic and religious group or culture [11]. The Roman, Byzantine, Seljuk and Ottoman empires have also influenced Hasankeyf's unique historical and cultural atmosphere, which is impossible to replicate [5].

Hasankeyf, as part of the broader Tigris basin, also performed a very important ecological role in maintaining biodiversity. For over 10,000 years, the Tigris River has been the mainstay to humans, plant, fish and reptile species and their habitats as a source of fresh water [6]. In Hasankeyf and its surroundings, 472 taxa belonging to 279 genera and 64 families were identified during a study. Many of the species of wild plants in the area are of significant cultural importance not only as edible food but also for economic use [12].

For economic growth to keep pace with population growth, Governments are often faced with controversial decisions, as they need to engage in large infrastructure projects to expand their production capacity to meet the growing needs of its citizens [13]. Such infrastructure projects pose a serious threat to archaeological sites, that could not only result in loss of cultural and natural heritage, but also have an impact on biodiversity and the environment through loss of habitat [12], [14]. The residents of Hasankeyf, have lost much of their cultural heritage as a result of the Ilisu dam project in South-eastern Turkey.

\section{THE ILISU DAM PROJECT, TURKEY}

The South-eastern Anatolia Project known as the GAP, is a mega project consisting of 22 dam projects and 19 hydropower schemes. This GAP project includes, the Ilisu dam on the Tigris river, the largest and last of its dam projects the Turkish Government embarked on to address its infrastructural needs [15]. Located in the South-eastern part of Turkey, the population of that area being mainly Kurdish, Ilisu is a small village along the Tigris. The initial attempt to build the dam in 1996 [16] suffered an early setback, during the environmental assessment stage. As a result of an environmental controversy, some members of the international consortium, and the Bank coordinating the financing withdrew from the Project [17]. After nearly 10 years of delay in getting the project off the ground [16] the construction of the Ilisu dam officially began in 2007 [18] with an estimated cost of \$2 billion and expected to generate as much electricity as a small nuclear reactor [19]. The dam, with a storage capacity of 10.4 billion cubic meters $(\mathrm{bcm})$, is for the purpose of hydroelectric power generation [20]. The dam commenced operation of its first turbine in 19 May 2020 and the second on 30 June 2020 [21]. 
From the perspective of the Turkish Government, the Ilisu dam project was important to address the country's dependence on energy imports and provide economic opportunities to the impoverished South-eastern region. With Turkey's demand for electricity and energy, second only to China, the Government argued that the country's dependence on imported coal and gas would decrease as the dam contributes to the economy, and irrigates local agricultural land. Further, in the context of Turkey's proximity to the large reserves of natural gas and oil reserves, it allows Turkey to strengthen its energy supply security in developing into a regional trade centre in energy [22].

Once completed, the dam would only have a functional life span of 30 to 50 years. The dam has generated much controversy due to its environmental impact and more pertinently the loss of natural and cultural heritage. Local residents were unhappy due to the loss of centuries old human settlements with its unique culture that was impossible to replicate [5]. The government's determination to build the dam was met with strong resistance from human rights and heritage activists as well [11]. To criticisms of environmental damage, the Government's response is that the Ilisu dam would result in major environmental benefits, as thermal power plants would reduce emissions of greenhouse gases from using coal and gas [22]. The Ilisu dam has also drawn protests from downstream co-riparians, Iraq and Syria, from time to time on the grounds that the Ilisu dam reduces the Tigris's water flow downstream [11]. Iraq's Mosul dam and the Ilisu dam share the same watershed, and the worst-case scenario assessment reveals that Ilisu's impact on Mosul could be as high as a $78 \%$ reduction in inflow [20]. From the perspective of Iraq and Syria, the Ilisu dam has given Turkey absolute control on the water flowing down from the river [11].

\section{HASANKEYF LOST}

Once the hydro-electric power plant began operations, Hasankeyf gradually submerged under water. Even though the Turkish Government was persistent in eventually building the dam, knowing that the historical and cultural heritage of Hasankeyf would be lost forever, they did take action in order to preserve some of the artefacts. Fig. 2 depicts the 500-year-old Zeynel Bey tomb in its original location, and Fig. 3 after its relocation.

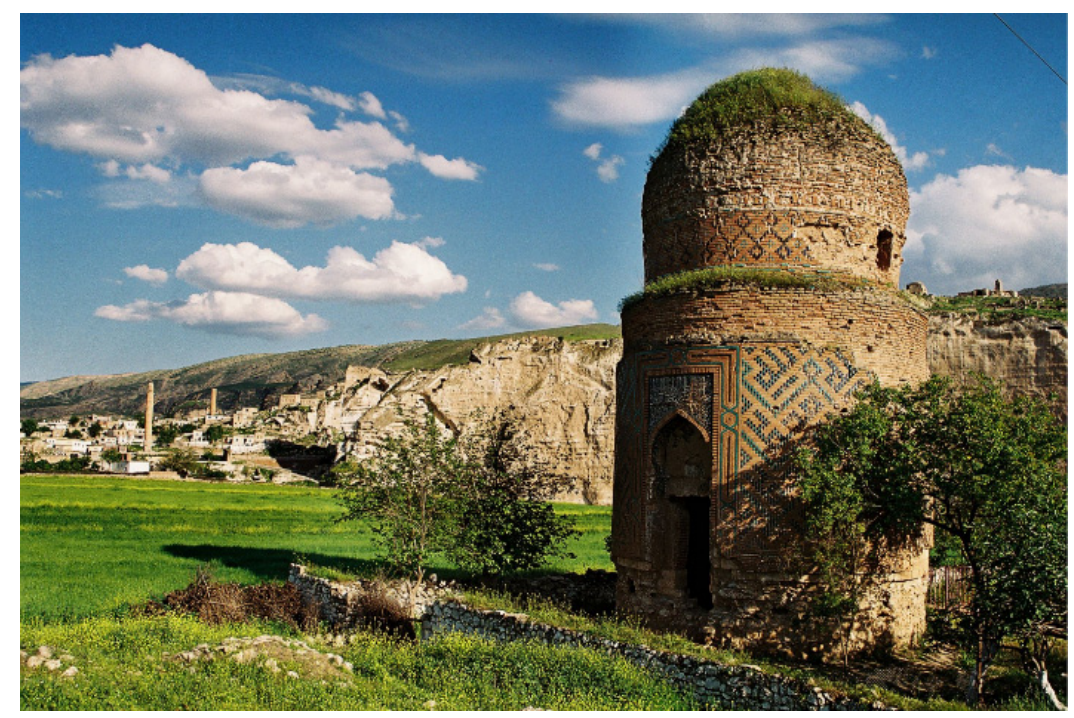

Figure 2: 500-year-old Zeynel Bey tomb in its original location. 


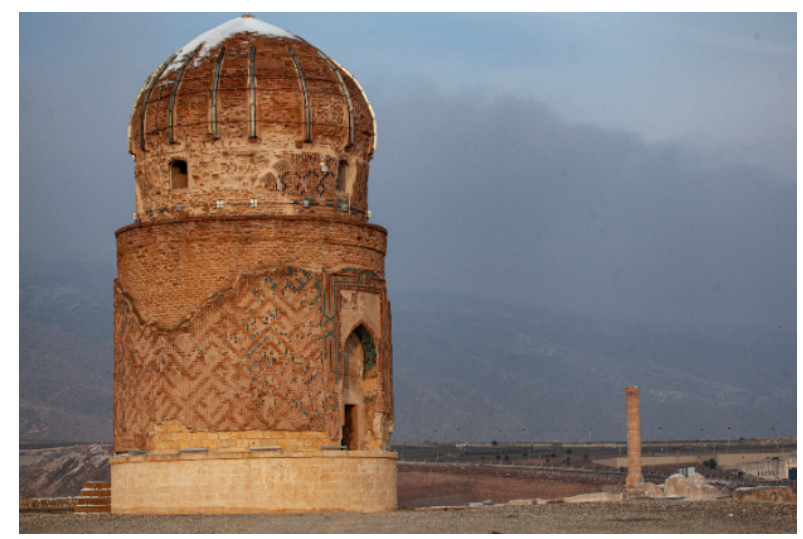

Figure 3: Zeynel Bey tomb after relocation.

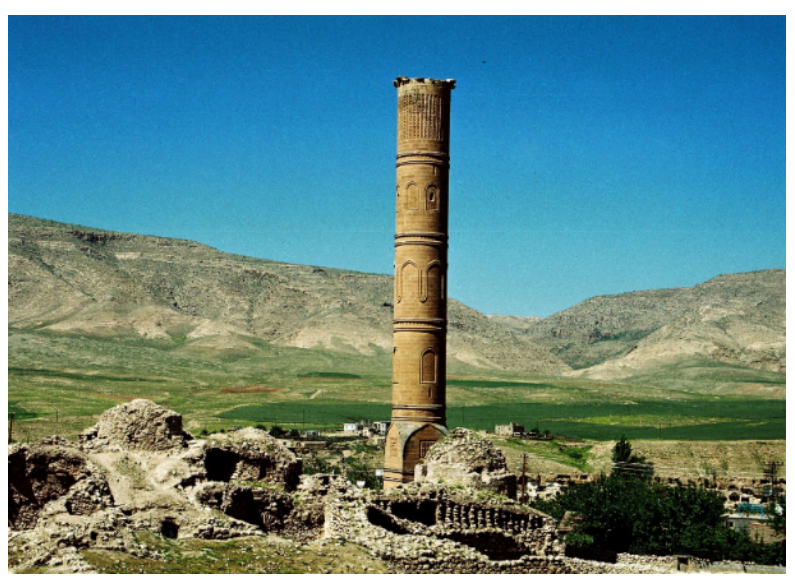

Figure 4: Iconic Minaret of Hasankeyf in its original location.

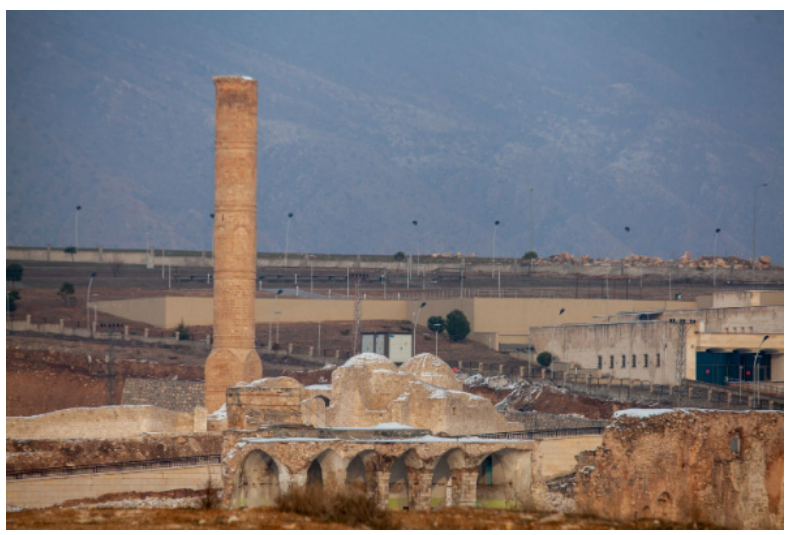

Figure 5: Iconic Minaret of Hasankeyf after relocation. 
Fig. 4 depicts the iconic Minaret of Hasankeyf in its original location and Fig. 5 after its relocation. When the Ilisu Dam was first approved in 1996 [11], archaeologists had been invited to start excavations in and around Hasankeyf, in order to assist in the preservation of artefacts before the flooding of the dam [23].

The flooding of Hasankeyf and surrounding areas resulted in the evacuation of approximately 200 villages and the resettlement of 78,000 people [18]. Pictured in Fig. 6 is the town of Hasankeyf when it was inhabited. The town has since been fully submerged.

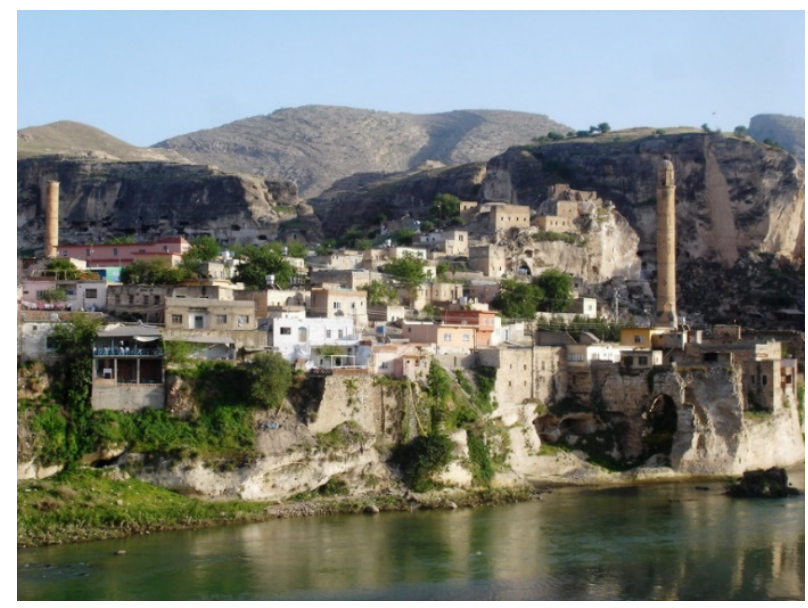

Figure 6: The township of Hasankeyf before evacuation.

As part of resettlement program the Turkish government established a new Hasankeyf town, located $3 \mathrm{~km}$ from the original town. Zeynel Bey tomb, Eyyubi Mosque and Artuklu Hamam were relocated to the newly established town. Furthermore, the Government established a museum dedicated to the artefacts salvaged from various excavations in and around Hasankeyf [5]. Fig. 7 is the town of Hasankeyf, after evacuation for resettlement, while it was being submerged. In the background the new Hasankeyf town is visible just below the mountains.

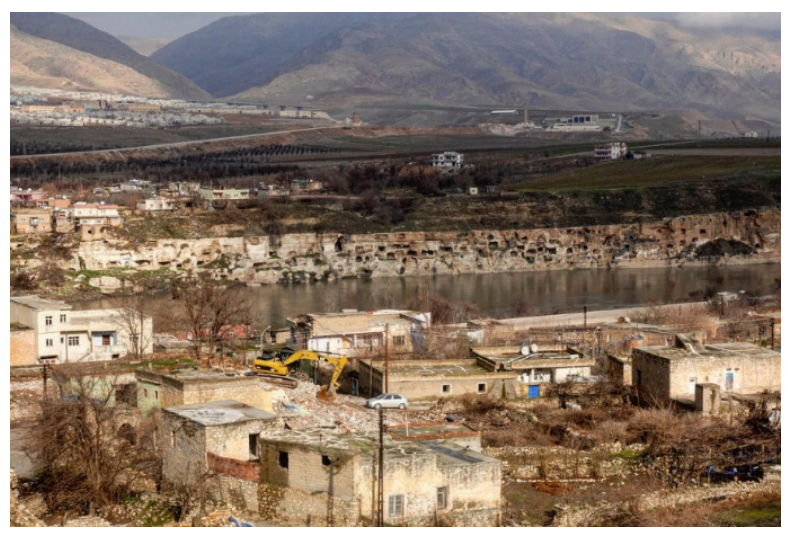

Figure 7: Hasankeyf town while it was being submerged. 
Many experts have pointed out that the museum did not actually salvage sufficient amounts of artefacts [24]. In fact, some artefacts could not be salvaged because they were too fragile to survive the relocation process [25]. With the exception of a few high positioned caves and artefacts the whole town, its ancient monuments, cave dwellings (Fig. 8) and churches remaining are completely submerged [5].

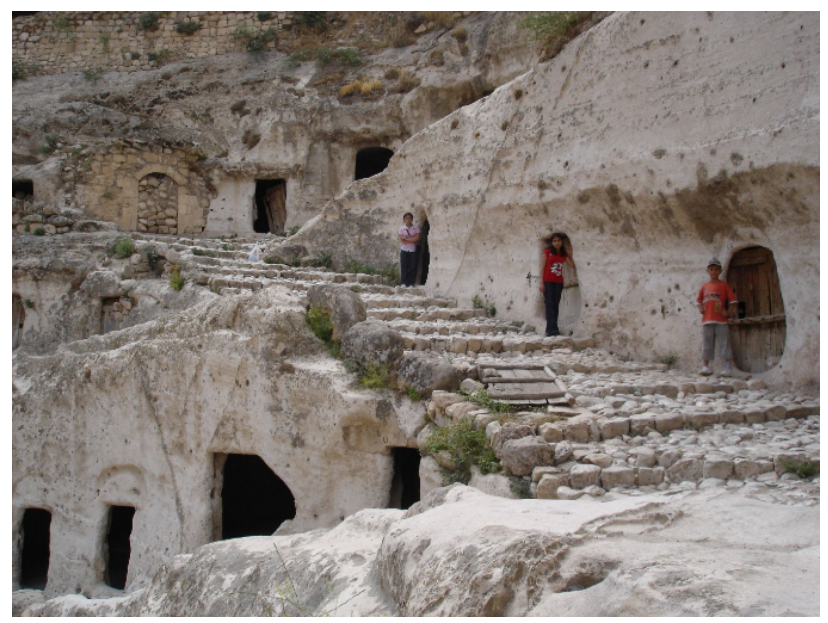

Figure 8: Cave dwellings before inundation.

\section{VALUING CULTURAL AND SOCIAL HERITAGE}

For the Kurdish people, who predominantly inhabited the reservoir area in Hasankeyf, prior to its inundation [16], this regional centre was their inheritance from the past, with emotional and spiritual links endowed by their cultural heritage [26]. Aykan argues, that the construction of the Ilisu Dam, which denied this group of people the right to participate in their cultural heritage, can be considered as a violation of their human rights [5]. However, as Hodder [27] states, the human rights argument seldom works as it tends to pit, humans against humans. In this case the argument would be pitting the Turkish Government, arguing for economic and social development for many groups, against the cultural heritage rights of one group.

In recognition of its historical relevance and unexplored archaeological sites, in 1978, the Ministry of Culture of the Republic of Turkey, had declared Hasankeyf a first-degree Conservation Area [28]. Some argued that Hasankeyf met at least nine of the ten requirements for World Heritage site status. Thus, being declared a UNESCO World Heritage site was another avenue for saving Hasankeyf. However, only a National Government could apply to UNESCO for World heritage status to be awarded to a site [5]. In 2013, based on scientific opinion a campaign was launched to collect signatures, which were presented to the Prime Minister of Turkey to support an application to UNESCO for world heritage status, but that was declined by the Prime Minister. By 2013, the Turkish Government had the necessary funding, after the initial delays, to continue work on the dam [29] to its completion. The arguments put forth by stakeholders, intent on preventing the loss of Hasankeyf, emphasising the aesthetic value of cultural and social heritage, the educational potential to future generations, though of immense value, are all subjective in nature and therefore proved ineffective against the tangible economic benefits of a development project. 
The construction of large infrastructure projects by governments, to meet the developmental needs of a country, are often controversial due to the loss of cultural and social heritage sites that are of value to its population. To counter this irretrievable loss, it is necessary to convince governments, using an economic argument that reflects the invaluable loss in future benefits. A cost benefit analysis based on the economic, and social benefits of the Ilisu dam, as proposed by the Turkish Government, could be performed easily from the perspective of the Government. But how does one represent cultural heritage in monetary terms? Cultural and social heritage, in some sites, is often intangible, and therefore valuation is subjective and difficult to ascertain in precise economic terms. To value the benefits of cultural and social heritage in economic terms' three models are explored in the context of Hasankeyf, and examined with respect to its ease of applicability, the socioeconomic conditions of the population in the threatened site and the prevailing 'political will' of the governing regime. According to Bedate et al. [30] Cultural heritage sites, share many aspects of public goods, although resources to maintain them are scarce. Similar to public goods cultural heritage sites provide benefits and externalities. Thus, all three models explore valuing cultural heritage as a public good [26], [30]. A public good, has no attached property rights assigned. Further, it has two key characteristics of non-excludability and non-rivalry and is also freely available. In other words, due to its key characteristics there will be no private provision of a public good, and will instead be provided by the Government.

Throsby [26] applied the Coase theorem to Australian cultural heritage in order to mimic a market solution and reach a voluntary negotiated outcome. The Coase theorem assumes that the stakeholders can be identified, property rights are well defined, transaction cost are negligible or zero and contracts are monitored and enforceable. As cultural heritage is analogous to a public good, it was concluded in the Australian case, that the assumptions of the Coase theorem could not be met, hence the solution was considered inapplicable. However, based on an extension of the Coase theorem being applied to Taiwan it is argued that when Governments are involved, they can set the market rules without creating a State monopoly and also the rules perform the function of property rights.

This particular case study is based on Taiwan which has an excellent record for postcolonial heritage conservation [31]. As in the Australian case, applying the Coase theorem to Hasankeyf is not possible due to lack of well-defined property rights. In addition, it cannot be assumed that there is political will for the Government to step in for conservation purposes as has been proven. Thus, it follows this model is inapplicable for Hasankeyf and other cultural sites in similar situations.

The travel cost method (TCM) focuses on the economic valuation of non-marketed resources and links travel costs faced by visitors to a cultural heritage site [32]. Two approaches may be applied. TCM is the longest established revealed preference approach [33]. The revealed preference method is based on observed behaviours and indirectly obtained data. In the stated preference method, individuals are asked to value their willingness to pay for a resource [34]. In this instance the methodology applied is contingent valuation, which is our third method of valuation, namely, the contingent valuation method (CVM). The TCM is based on costs incurred to visit a site including flights, accommodation and meals, and an estimation of the value of their time spent travelling from their homes to their accommodation while visiting and the time spent travelling from their accommodation to tour sites.

The two methods identified, to value Travel cost and cultural heritage using willingness to pay, are based on demand that has been created, and, in most cases with the assistance of the Government, such that people are willing to pay, to travel to the destination in the case of TCM, and, for non-priced benefits in the case of CVM. Both methods, in order to be 
applied, require already established demand for the cultural product or experience such that it is possible to conduct surveys to estimate the economic benefit of consuming these non market goods [35].

The international community and NGOs were very supportive in lobbying and looking for the means of saving Hasankeyf. In applying these methods to Hasankeyf, data to be collected via questionnaires and surveys could have been administered with the assistance of the international community to estimate the demand for travel and the willingness to pay for a non-market resource such as the cave dwellings in Hasankeyf or Zeynel Bey's tomb. If sufficient interest in Hasankeyf could have been built up for tourism purposes, convincing the Government of its economic value as a future source of wealth generation may have been possible. Of course, where Governments recognise the value of cultural goods for its economic and social benefits, especially in terms of the economic benefit that could be garnered from tourism, preservation will be considered as a viable option. In this instance, methods such as the Travel Cost Method TCM [32] or the Contingent Valuation Method CVM [34] could be applied to assess the economic viability of preserving cultural heritage, provided there are no conflicting development priorities. However, the low socioeconomic status of the population would have meant the necessary investment would have been lacking unless it came from the Government. The question remains whether the political will of the government could have been influenced in its favour.

In conclusion, despite the fact that cultural heritage is widely recognised by Governments, academics and public authorities as essential in building social capital [3], it is often sidestepped when faced with the need for infrastructure development to meet the demands of growing populations. Among the many infrastructure projects, dams in particular are controversial. Across the Middle East and North Africa, Marchetti et al. [36] have identified approximately $1,300 \mathrm{~km}$ of ancient rivers and 2,500 archaeological sites that have been submerged in the process of dam construction.

Hasankeyf, a unique site of immense cultural and social value has been inundated as a result of the Ilisu dam project. The Government justified its actions based on the demand for energy to meet the needs of a growing population. Despite calls from the international community and the local population the dam is now in operation. Hasankeyf, when it was declared a first-degree Conservation Area, in 1978, was not being recognised for its potential for tourism. Rather the emphasis was more on its cultural worth for posterity, its research potential due to its past, its biodiversity, and its unique history. The undertaking in 2013, to seek UNESCO World heritage site recognition, was also a desperate attempt to save Hasankeyf for the same reasons. These are all valid reasons for preservation of the cultural and natural heritage of Hasankeyf. However, only an economic argument may be considered if at all when it comes to cultural heritage.

In the case of Hasankeyf, where the socio-economic status of the population is low attempting to quantify its cultural worth in economic terms would have been near impossible or possibly subjective. Under these circumstances trying to convince a national Government bent on economic development, building a dam of political significance to change its plans is impossible as has been proven. Despite the loss, some lessons have been learned. The importance of focussing on economic arguments to prevent the loss of heritage sites as a result of development projects is undeniable. There are proven rigorous methods such as the TCM and the application of CVM to cultural heritage that are easily applicable in quantifying the value of non-marketable resources. It is important to focus on the need for such valuations to prevent the destruction of cultural heritage sites. 


\section{ACKNOWLEDGEMENT}

All photographs are courtesy of Seyda Goyan. We greatly appreciate his assistance.

\section{REFERENCES}

[1] UNESCO World Heritage Centre, Convention concerning the protection of the world cultural and natural heritage. 1972. https://whc.unesco.org/archive/convention-en.pdf.

[2] Liburd, J. \& Becken, S., Values in nature conservation, tourism and UNESCO world heritage site stewardship. Journal of Sustainable Tourism, 25(12), pp. 1719-1735, 2017.

[3] Murzyn-Kupisz, M. \& Działek, J., Cultural heritage in building and enhancing social capital. Journal of Cultural Heritage Management and Sustainable Development, 2013.

[4] Putnam, R.D., Bowling Alone: The Collapse and Revival of American Community, Simon and Schuster, 2000.

[5] Aykan, B., Saving Hasankeyf: Limits and possibilities of international human rights law. International Journal of Cultural Property, 25(1), 2018.

[6] Röhr, C., Archaeology in 21 ST c: Case of Hasankef, Turkey.

[7] Carter, T., Moir, R., Wong, T., Campeau, K., Miyake, Y.\& Maeda, O., Hunter-fishergatherer river transportation: Insights from sourcing the obsidian of Hasankeyf Höyük, a Pre-Pottery Neolithic A village on the Upper Tigris (SE Turkey). Quaternary International, 574, pp. 27-42, 2021.

[8] Maeda, O., Lithic analysis and the transition to the Neolithic in the Upper Tigris Valley: Recent excavations at Hasankeyf Höyük. Antiquity, 92(361), pp. 56-73, 2018.

[9] Tatsumi, Y., A Neolithic sedentary hunter-gatherer settlement with densely arranged buildings: Results of geophysical prospection at Hasankeyf Höyük in south-eastern Anatolia. Archaeological Prospection, 27(4), pp. 329-342, 2020.

[10] Karul, N., Gusir Höyük. The Neolithic in Turkey, 1, pp. 1-7, 2011.

[11] Warner, J., The struggle over Turkey's Ilısu Dam: Domestic and international security linkages. International Environmental Agreements: Politics, Law and Economics, 12(3), pp. 231-250, 2012.

[12] Yeşil, Y. \& İnal, İ., Traditional knowledge of wild edible plants in Hasankeyf (Batman Province, Turkey). Acta Societatis Botanicorum Poloniae, 88(3), p. 3633, 2019.

[13] Ministry of Foreign Affairs, Turkey's energy strategy. https://www.mfa.gov.tr/ turkeys-energy-strategy.en.mfa. Accessed on: 15 Apr. 2021.

[14] Machat, C., Ziesemer, J. \& Petzet, M., Heritage at Risk: ICOMOS World Report 20062007 on Monuments and Sites in Danger, Hendrik Bäßler Verlag, 2008.

[15] Balat, M., Southeastern Anatolia Project (GAP) of Turkey and regional development applications. Energy Exploration \& Exploitation, 21(5), pp. 391-404, 2003.

[16] Eberlein, C., Drillisch, H., Ayboga, E. \& Wenidoppler, T., The Ilisu dam in Turkey and the role of the export credit agencies and NGO networks. Water Alternatives, 3(2), p. 291, 2010.

[17] Égré, D. \& Senécal, P., Social impact assessments of large dams throughout the world: Lessons learned over two decades. Impact Assessment and Project Appraisal, 21(3), pp. 215-224, 2003.

[18] Hommes, L., Boelens, R. \& Maat, H., Contested hydrosocial territories and disputed water governance: Struggles and competing claims over the Ilisu Dam development in southeastern Turkey. Geoforum, 71, pp. 9-20, 2016. 
[19] Hockenos, P., Turkey's dam-building spree continues, at steep ecological cost, 2019. https://e360.yale.edu/features/turkeys-dam-building-spree-continues-at-steepecological-cost. Accessed on: 5 Apr. 2021.

[20] Al-Madhhachi, A.S., Rahi, K.A. \& Leabi, W.K., Hydrological impact of Ilisu dam on Mosul dam; the river Tigris. Geosciences, 10(4), p. 120, 2020.

[21] Bimay, M., Spatial, social and environmental effects of forced displacement due to dam construction: The case of Hasankeyf. Econharran, 5(7), pp. 49-83.

[22] Ministry of Foreign Affairs, Turkey's energy strategy. https://www.mfa.gov.tr/ turkeys-energy-strategy.en.mfa. Accessed on: 15 Apr. 2021.

[23] Kucukgocmen, A., Turkey starts filling huge Tigris river dam, activists say. https://www.reuters.com/article/us-turkey-dam-idUSKCN1US194. Accessed on: 20 Apr. 2021.

[24] Drazewska, B., Hasankeyf, the Ilisu Dam, and the existence of "Common European Standards" on cultural heritage protection. Santander Art and Culture Law Review, 4(2), pp. 89-120, 2018.

[25] Topal, T. \& Kaya, Y., Assessment of deterioration and collapse mechanisms of dolomitic limestone at Hasankeyf Antique City before and after reservoir impounding (Turkey). Environmental Earth Sciences, 75(2), p. 131, 2016.

[26] Throsby, C.D., Paying for the past: Economics, cultural heritage, and public policy. Australia's Economy in Its International Context, p. 527, 2006.

[27] Hodder, I., Cultural heritage rights: From ownership and descent to justice and wellbeing. Anthropological Quarterly, 83(4), pp. 861-882, 2010.

[28] Kocabas, H.M., Planning in fragile sites in Turkey: In case of Hasankeyf. PLANNING TIMES - You better keep planning or you get in deep water, for the cities they are achangin. Proceedings of 18th International Conference on Urban Planning, Regional Development and Information Society, CORP - Competence Center of Urban and Regional Planning, pp. 691-700, 2013.

[29] Gourlay, W., Turkey's Hasankeyf: The plight of archaeological and architectural treasures in Southeast Anatolia. TAASA Review, 14, 2013.

[30] Bedate, A., Herrero, L.C. \& Sanz, J.Á., Economic valuation of the cultural heritage: Application to four case studies in Spain. Journal of Cultural Heritage, 5(1), pp. 101111, 2004.

[31] Go, V.K. \& Lai, L.W., Learning from Taiwan's post-colonial heritage conservation. Land Use Policy, 84, pp. 79-86, 2019.

[32] Torres-Ortega, S., Pérez-Álvarez, R., Díaz-Simal, P., Luis-Ruiz, D., Manuel, J. \& Piña-García, F., Economic valuation of cultural heritage: Application of travel cost method to the National Museum and Research Center of Altamira. Sustainability, 10(7), p. 2550, 2018.

[33] Blakemore, F. \& Williams, A., British tourists' valuation of a Turkish beach using contingent valuation and travel cost methods. Journal of Coastal Research, 24(6(246)), pp. 1469-1480, 2008.

[34] Majumdar, S., Deng, J., Zhang, Y. \& Pierskalla, C., Using contingent valuation to estimate the willingness of tourists to pay for urban forests: A study in Savannah, Georgia. Urban Forestry \& Urban Greening, 10(4), pp. 275-280, 2011.

[35] Venkatachalam, L., The contingent valuation method: A review. Environmental Impact Assessment Review, 24(1), pp. 89-124, 2004.

[36] Marchetti, N., Curci, A., Gatto, M.C., Nicolini, S., Mühl, S. \& Zaina, F., A multi-scalar approach for assessing the impact of dams on the cultural heritage in the Middle East and North Africa. Journal of Cultural Heritage, 37, pp. 17-28, 2019. 